\title{
The Economic Empowerment of Women in Uganda Through Mushroom Production
}

\author{
Ibrahim Mayanja*, Tolga Tipi
}

Department of Agricultural Economics, Faculty of Agriculture, Uludağ University, Görukle Campus 16059 Nilufer/Bursa, Turkey

\begin{tabular}{l} 
A R T I C L E I N F O \\
Research Article \\
Received 23 May 2017 \\
Accepted 27 September 2017 \\
\hline
\end{tabular}

Keywords:

Mushroom

Production

Empowerment

Women

Benefit Cost Ratio (BCR)

Return On Investment (ROI)

*Corresponding Author:

E-mail: ibrahimmayanja9@gmail.com \begin{abstract}
A B S T R A C T
This study focuses on empowering women both in peri-urban and rural areas through mushroom production. It was conducted in Kampala Metropolitan area-Uganda, during October 2016. It focused on estimating profits, conducting benefit-cost analysis/ratio (BCR) and return on investment (ROI), finding reasons as to why women involved in the mushroom production and identifying the constraints of mushroom farming from the perspective of women as well as the possible solutions to the constraints. 29 women were interviewed face to face through the use of the questionnaires. The study revealed an average net profit of 3,464.28 US dollars, BCR of 3.84 and ROI of 2.84 per farm in a period of three months. Our study revealed that mushroom production is a profitable enterprise for women. The major reason for women to involve in mushroom was to earn income. However, a range of other reasons was given such as fast maturity of mushrooms, availability of market, healthy benefits of mushrooms, etc. were the most important reasons. The problems faced by women farmers were ranked from the most pressing problem to the least pressing problem in this order; Low market prices per kilogram of mushroom, scarcity of cotton during some seasons, poor quality mushroom spawn supplied to farmers by breeders, inadequate extension, and advisory services were the most observed problems among others. The suggested solutions were organizing farmers into groups or cooperatives in order to negotiate for better markets locally and abroad together with the help of government, researchers to carry out more research on the suitability of other substrates like bagasse other than relying on only cotton, ensuring that mushroom spawn breeders conform to the set standards of quality spawn production and re-equipping local extension workers with knowledge regarding mushroom production among others.
\end{abstract}

DOI: https://doi.org/10.24925/turjaf.v5i11.1401-1406.1345

\section{Introduction}

Uganda is endowed with a variety of resources ranging from fertile soils, two rainfall seasons and minerals. Uganda is also blessed with a mild tropical climate and optimum temperatures for growing major varieties of mushrooms. Uganda is also considered the food basket of Africa given its potential to produce food to feed the whole of Africa. Uganda's total population is 34.8 million people of which $51 \%(17.9 \mathrm{~m})$ are female (UBOS, 2014). Over $80 \%$ of Uganda's population live in the rural areas, and rural employment constitutes of mainly agriculture. Women constitute $76 \%$ of agriculture labour force compared to 65\% of men (OECD, 2015; MoFPED, 2014) and subsistence farming is by far the main source of employment were $60 \%$ of the population survives on subsistence agriculture (UBOS, 2014). Agriculture contributes $24.4 \%$ to country's Gross Domestic Product (World Bank, 2016). Although women constitute the highest labour force in the agriculture sector, they are faced with countless challenges that are influenced by the gendered, social and geographical determinants for women's employment (World Bank, 2014). All these limit and constrain women's employment in the agriculture sector for example, despite the main role played by women in agriculture, it is estimated that only $7 \%$ of them own and control the use of land. Women's rights tend to be limited to access, whereas men are more inclined to enjoy the ownership rights and ultimately control the proceeds from the land.

Consequently, many landless potential farmers especially women cannot easily access land because of the costs involved, cultural norms and the threats imposed by the existing overlapping land rights even though women provide $70-80 \%$ of the agricultural labour workforce (Malakar et al., 2016).Therefore, shortage of arable land amongst women and the continuous neglecting of responsibilities at home by men, there is a 
need to empower women economically through engaging in mushroom production that requires a small piece of land and locally available materials. Women's involvement in mushroom production reduces workload, increases income, food security and uplifts their status in society since it can be done inside a house or on an open access piece of land (Kiguli, 2003). Mushroom growing is still considered a women's occupation in Uganda and therefore realisation of women's rights to land, and household property will be a key to further improve investment in mushroom cultivation (Malakar et al., 2016). Ugandan women have exhibited high entrepreneur potential and according to Mastercard Index of Women's Entrepreneurship (MIWE) report released recently, it was revealed that $34.8 \%$ of businesses in Uganda are owned by women, making it the top performing country in the world, the high index is attributed to high resilience of women, determination and the desire to provide for their families (Anonymous, 2017).

Mushrooms provide important nutrients, including selenium, potassium, riboflavin, niacin, vitamin D, proteins, and fibre. All together with a long history as a food source, mushrooms are important for their healing capacities and properties in traditional medicine. It has beneficial effects on health and treatment of some diseases (Valverde et al, 2015). Increased cultivation and consumption of mushroom can therefore help raise the nutritional status of Ugandans by providing an extra source of protein, valuable minerals and vitamins especially to children, pregnant women, and people infected with HIV/AIDS and all other categories of people as well as improving household income in periurban and rural areas where women have access to small pieces of land. Mushroom industry is providing full or part-time employment to rural and urban poor and marginal people in many developing countries (Ferchak and Croucher, 2001).

All Ugandans, except the nomadic pastoralists, appreciate mushrooms as a food delicacy and some tribes even use them as medicine and as fertility enhancers. Mushrooms are still considered a delicacy because of their scarcity and unique flavour (Malakar et al., 2016). Commercial introduction of mushrooms in Uganda started in 1989 following the government introduction of Oyster mushrooms from Egypt to National Agriculture Research Laboratories (NARL) Kawanda (Kyobutungi, 2014), but up to now there are few farmers involved in its cultivation and the actual number of mushroom growers in Uganda is not known since no reliable census has been undertaken (Malakar et al., 2016).

There is a thriving market for local edible wild mushrooms, especially along motorways (Nshemereirwe, 2004). The uniqueness of mushroom growing is that it can be done with low capital investment, it requires minimal space, and it is a home based activity that is environmentally friendly (Anonymous, 2009). Therefore, it is a viable venture for women since they face a problem of inequality in land acquisition and ownership.

Economic empowerment of women enhances national productivity, generate employment but also help to develop economic independence, personal and social capabilities among rural women which includes building self-confidence, enhances awareness, feeling sense of achievement, increased social interaction, improvement in leadership qualities, involvement in solving problems related to women and community, increased decision making capacity at family and community levels (Sathiabama, 2010). Mushroom production has made a significant impact in lives of women in Uganda by improving their standards of living and empowering them economically which has enabled widows and single mothers to support their families to live a decent life (Anonymous, 2012; Anonymous, 2015). Mushroom production has created awareness amongst women, created a sense of belonging and has led to the economic empowerment of landless women as many have found it a good option for generating additional income for the family (Singh et al., 2014). In a study conducted in India amongst women farmers, it was observed that mushroom cultivation was a profitable enterprise and played an important role in their economic empowerment (Awasthi et al., 2015).

From the above perspective, our study aims at assessing the economic viability of mushroom production amongst women-owned mushroom enterprises, identifying the reasons as to why women engaged in mushroom production, identifying the problems facing mushroom production in the perspective of women as well as the possible solutions to the problems as a basis of boosting mushroom production in Uganda but specifically amongst women.

\section{Materials and Methods}

The study area covered Kampala Metropolitan. It is an area about 100 kilometres from the city centre. The study area covered three of the four divisions of Kampala including Kawempe, Makindye, Lubaga, and Nakawa. It also covered some parts of Wakiso like Kawanda, Entebbe, etc., some parts of Mukono and Mpigi like Maya. It was selected as a study area because of the thriving market in the area for mushroom, availability of farmers and people have limited pieces of land which would serve as an example to the rest of the country in similar circumstances. The selected farmers were based on their participation in mushroom production. The primary data was obtained through cross-sectional research design where face to face interviews were conducted using questionnaires administered to 29 female farmers, and secondary data was also used. To calculating costs, the opportunity cost for owner inputs and the actual price paid by the farmers for purchased inputs were considered. Mushroom farmers were categorized into three groups basing on the number of gardens (bags) they cultivate, i.e., 50-500, 501-1000 and 1001+ gardens. The average fixed costs were calculated based on the threemonth basis by dividing the value of a fixed item into its estimated economic life. The estimated economic life for a semi-permanent housing structure was one year, metallic drum (barrel) was two years, weighing scale was 
three years, knapsack sprayer or watering-can was two years and tarpaulin was two years. All the average costs were considered on a three months basis because one production period for commercial mushroom farmers takes three months.

\section{Data Analysis and Presentation}

Several approaches are used in this report to determine the major objective of this study. The costs involved in the mushroom production are analysed using SPSS 20 ranging from demographic data to the problems faced by farmers in mushroom production. Benefit Cost Ratio (BCR) is calculated by obtaining the average value from the total number of respondents involved in the study depending on their level of production, and an overall average has also been obtained. BCR is obtained by dividing the total discounted benefits by total discounted costs involved in an enterprise.

Benefit Cost Ratio $=\frac{\text { Total Benefits }}{\text { Total Costs }}$

A BCR greater than one means the benefits outweigh the costs and the investment should be considered. If the ratio is less than 1 , the costs outweigh the benefits. If the $\mathrm{BCR}$ is equal to 1 , the benefits equal the costs.

The second technique which has been used to determine the profitability of mushroom enterprises is the Return on Investment (ROI) which is similar to BCR but compares the net benefit (total discounted benefits minus total discounted costs) to costs. The ROI indicates how much of the investment policymakers or investors can expect to receive as a benefit.

Rate on Investment $=\frac{\text { Total Benefits-Total Costs }}{\text { Total Benefits }} \times 100$

If the ROI is positive, the benefits exceed the costs, and the investment should be considered. A negative ROI means that the costs outweigh the benefits. The ROI of 0 means the benefits equal the costs. The ROI value is expressed as a percentage.

The third technique was to find out the net profit of mushroom enterprise which was calculated by deducting total fixed costs from gross profit (Total Benefits) as shown below.

\section{Net Profit $=$ Gross profit-Total Fixed Costs}

\section{Results and discussion}

The Social Economic Characteristics of Respondents Age

The 29 mushroom farmers who were interviewed, $48.3 \%$ belonged to the age group between 20 and 30 , $24.1 \%$ of the respondents belonged to age group between 31 and $40,20.7 \%$ and $6.9 \%$ of the respondents belonged to the age groups between 41-50 and 51 and above respectively. This implies that majority of the women involved in the mushroom production are mature adults and youth between 20-30. Mushroom production is also important to women in the retirement age as shown in Table 1 below.

\section{Marital Status of The Respondents}

The survey revealed that $82.8 \%$ of the women who grow mushrooms were married, $10.3 \%$ of women were widowed and $6.9 \%$ of the respondents were single. This indicates the high desire for women to earn income in order to support their families to live a decent life.

\section{The Level of Education}

The majority of the women were diploma and degree holders $62 \%, 31 \%$ of the respondents were secondary school leavers, $7 \%$ of the respondents were high school leavers, and no respondent had primary school education as shown in Table 3 below. Women had varying experience in mushroom production, a woman with the longest experience had spent 21 years and the minimum was one year, and on average each farmer had experience of approximately three years. Our study reveals that educated women have actively involved in mushroom production which is a resource that can be utilised to boost mushroom production amongst women.

Table 1 Age groups of respondents

\begin{tabular}{l|cc}
\hline \multicolumn{1}{c|}{ Age groups } & Frequency & Percent $(\%)$ \\
\hline $20-30$ & 14 & 48.3 \\
$31-40$ & 7 & 24.1 \\
$41-50$ & 6 & 20.7 \\
51 and above & 2 & 6.9 \\
Total & 29 & 100.0 \\
\hline
\end{tabular}

Table 2 Marital Status of Respondents

\begin{tabular}{l|cc}
\hline \multicolumn{1}{c|}{ Marital status } & Frequency & Percent $(\%)$ \\
\hline Married & 24 & 82.8 \\
Widowed & 3 & 10.3 \\
Single & 2 & 6.9 \\
Total & 29 & 100.0 \\
\hline
\end{tabular}

Table 3 The level of education of respondents

\begin{tabular}{l|cc}
\hline Level of education & Frequency & Percent $(\%)$ \\
\hline Primary & 0 & 0.0 \\
Secondary & 9 & 31.0 \\
High School & 2 & 7.0 \\
Diploma and Degree & 18 & 62.0 \\
Total & 29 & 100.0 \\
\hline
\end{tabular}

\section{Reasons for Growing Mushrooms}

Women majorly got involved in the mushroom production to earn income. However, a range of other reasons were given and were ranked according to more important, important and less important. Our study observed that $96.6 \%$ and $3.4 \%$ of women considered the fast maturity of mushrooms as the more important and important reason respectively for them to select mushroom production. Our study further shows that $89.7 \%$ and $10.3 \%$ of women considered the availability of the market for mushrooms as the most important and important reason respectively. The study again indicates that $58.6 \%$ and $31.1 \%$ of women considered healthy 
benefits associated with eating mushrooms as the most important and important reason respectively whereas $10.3 \%$ considered it less important reason for them to choose mushroom production. This study further indicates that $31 \%$ and $55.2 \%$ of women considered mushrooms being disease free compared to other crops as the more important and important reason respectively whereas $13.2 \%$ considered it a less important reason. Our study further shows that $20.7 \%$ and $24.1 \%$ of women considered less capital needed to start mushroom production as the more important and important reason respectively whereas $55.2 \%$ considered it less important.
Our study further reveals that neither government support nor availability of free mushroom spawn was the reasons as to why they selected mushroom production since they have never received any of them. The other reasons as to why farmers selected mushroom production were; mushrooms requires small piece of land to cultivate, mushrooms are tasty (delicious) and can easily be cultivated as a side business, $6.9 \%$ and $67 \%$ of women considered it more important and important reasons respectively where as $26.1 \%$ considered other reasons less important as shown in Table 4 below.

Table 4 Reasons why farmers grow mushrooms

\begin{tabular}{l|cccccc}
\hline \multirow{2}{*}{ Particulars } & \multicolumn{2}{|c}{ More Important } & \multicolumn{2}{c}{ Important } & \multicolumn{2}{c}{ Less Important } \\
\cline { 2 - 6 } & Frequency & Percent $(\%)$ & Frequency & Percent (\%) & Frequency & Percent (\%) \\
\hline Fast Maturity & 28 & 96.6 & 1 & 3.4 & 0 & 0 \\
Disease-free & 9 & 31.0 & 16 & 55.2 & 4 & 13.8 \\
Less capital & 6 & 20.7 & 7 & 24.1 & 16 & 55.2 \\
Market availability & 26 & 89.7 & 3 & 10.3 & 0 & 0 \\
Healthy benefits & 17 & 58.6 & 9 & 31.1 & 3 & 10.3 \\
Government support & 0 & 0 & 0 & 0 & 29 & 100 \\
AFMS & 0 & 0 & 0 & 67.0 & 29 & 100 \\
Others & 2 & 6.9 & 20 & & 7 & 26.1 \\
\hline
\end{tabular}

AFMS: Availability of free mushroom spawn, (i) Total sample size is 29

Table 5 Agriculture incomes from mushroom production

\begin{tabular}{l|cccc}
\hline \multicolumn{1}{c|}{ Particulars } & $50-500$ & $501-1000$ & $1001+$ & Average \\
\hline Net profit $(\$)$ & 640.07 & 1.271 .24 & 39.697 .55 & 3.464 .28 \\
Opportunity cost of family labour $(\$)$ & 52.88 & 52.88 & 132.19 & 79.31 \\
Total $(\$)$ & 692.95 & 1.324 .12 & 39.829 .74 & 3.543 .59 \\
\hline
\end{tabular}

Table 6 Returns, CBR and ROI of mushroom production

\begin{tabular}{l|cccc}
\hline \multicolumn{1}{c|}{ Particulars } & $50-500$ & $501-1000$ & $1001+$ & Average \\
\hline Gross profit $(\$)$ & 921.58 & 1.716 .01 & 45.326 .30 & 4.148 .34 \\
Net profit (\$) & 640.07 & 1.271 .24 & 39.697 .55 & 3.464 .28 \\
Cost-Benefit Ratio & 3.47 & 3.91 & 7.44 & 3.84 \\
Return on Investment & 2.47 & 2.91 & 6.44 & 2.84 \\
\hline
\end{tabular}

(i) Total sample size is 29; (ii) 1 US\$ $=3404.205$ Uganda Shillings (October 2016); (iii) Duration of mushroom cultivation is three months. Thus all costs are calculated based on three months.

\section{Economic Analysis of Mushroom Production}

The cost items in the mushroom farming included different types of fixed, variable and opportunity costs. On the return side, gross return included revenue from sales of fresh mushrooms.

\section{Fixed Costs}

These include costs whose economic life is more than one year, and they included housing, weighing balance, drum, tarpaulin and knapsack sprayer or watering can.

\section{Variable Costs}

Variable cost share is the largest amount in the total cost of mushroom farming since they vary with the level of output. They include mushroom spawn, cotton, gauze or string, polythene bags, water costs, firewood, packaging materials, the cost of training, rice bran, agriculture lime, labour costs both hired and family labour in mushroom production.

\section{Labour Costs}

Labour cost included family labour and hired labour costs. The family labour cost was calculated on the principle of opportunity cost. The hired labour cost was calculated on the basis of the labour employed at the local market price. Labour cost is one of the main cost items in agriculture, and it is also true in mushroom farming. The case of small and medium farm owners, family members provide their labour and hire out a person to help them during the preparation of the mushroom gardens and he is paid depending on work done. However, for large farms, not only owner and family labour is used but also hired labour is used which is paid on a monthly basis. The opportunity cost of labour increases with the number of gardens cultivated by farmers.

The table below shows the average net profit is 3.464.28 US dollars and shows the average cost-benefit ratio of 3.84 and return on investment of 2.84 in three months. This implies that mushroom production is a 
profitable enterprise for women. The more gardens (bags) a farmer cultivates, the more yields obtained, and therefore the net profit obtained also increases.

\section{Conclusions and Recommendations}

The mushroom sector faces some challenges which cut across as shown in Table 7 below. The suggested solutions to the problems are also shown of which if they are solved it will boost the mushroom sector in Uganda, improve household income and raise the status of women in Uganda as well as enabling women to contribute tremendously to the development of their nation.

The estimates of benefit-cost analysis, net profit, and return on investment indicate that on average all women who involved in mushroom production made profits implying that mushroom production is a profitable enterprise and farmers reaped benefits out of it though it is neglected in terms of prioritisation during resource allocation by the government and other development partners.

Women can be organised into Savings and Credit Cooperatives (SACCOs) or self-help groups where they can increase their bargaining power, get better markets and access other services easily among others. It is possible for mushroom enterprises to be established in peri-urban areas (even in slums) and also in villages where the produce can be sold locally or dried and later transported to urban markets.

Table 7 Problems and solutions

\begin{tabular}{|c|c|}
\hline Problem & Solutions \\
\hline Low market prices & $\begin{array}{l}\text { Encouraging women to form groups/cooperatives, gathering and } \\
\text { disseminating market information among them, negotiating for better } \\
\text { markets locally \& abroad as well as sensitising Ugandans about the health } \\
\text { benefits associated with consuming mushrooms. }\end{array}$ \\
\hline $\begin{array}{l}\text { Scarcity and expensive cost of cotton } \\
\text { seed hulls in some seasons }\end{array}$ & $\begin{array}{l}\text { The government needs to give subsidies or offer free cotton seed hulls to } \\
\text { women groups/farmers as the case with other crops and also promote using } \\
\text { other substrates like bagasse amongst women. }\end{array}$ \\
\hline $\begin{array}{l}\text { Scarcity and poor quality of mushroom } \\
\text { spawn supplied to women farmers. }\end{array}$ & $\begin{array}{l}\text { Uganda National Bureau of Standards should effectively monitor the spawn } \\
\text { producing companies to ensure that they conform to the set standards of } \\
\text { spawn so that quality spawn is supplied to women, the government also } \\
\text { needs to support mushroom spawn breeders with necessary infrastructure to } \\
\text { produce quality \& adequate spawn in time. }\end{array}$ \\
\hline $\begin{array}{l}\text { Inadequate extension services to } \\
\text { women. }\end{array}$ & $\begin{array}{l}\text { Training and re-training local extension workers about mushroom production } \\
\text { and the activities involved so that they can reach to more women. }\end{array}$ \\
\hline High temperatures. & $\begin{array}{l}\text { Encouraging women to construct better suitable structures that easily } \\
\text { regulate temperature and make watering easier. }\end{array}$ \\
\hline Less capital to expand & $\begin{array}{l}\text { Through organising Saving and Credit Cooperative organisations (SACCOs) } \\
\text { to raise capital amongst women and acquire loans at cheaper interest rates } \\
\text { from the women fund created by the government. }\end{array}$ \\
\hline Termites, snails, fungus and infections & $\begin{array}{l}\text { Ensuring hygiene during the preparation of mushroom gardens, using } \\
\text { appropriate fungicides, insecticides, etc. and researchers need to conduct } \\
\text { more research about these emerging challenges. }\end{array}$ \\
\hline Perishability nature of mushroom & $\begin{array}{l}\text { Improving marketing infrastructure such as cold storage facilities and proper } \\
\text { arrangements are needed by drying \& processing units for the management } \\
\text { of surplus mushroom during bumper production. }\end{array}$ \\
\hline Difficulty in obtaining water & $\begin{array}{l}\text { Investing in water harvesting technologies and obtaining water via National } \\
\text { Water and Sewerage Cooperation which is cheaper. }\end{array}$ \\
\hline Others & $\begin{array}{l}\text { Including mushroom enterprise in government agriculture programs, } \\
\text { emphasising value addition and designing a deliberate policy aimed at } \\
\text { supporting women involvement in mushroom production as a way of } \\
\text { empowering them economically. }\end{array}$ \\
\hline
\end{tabular}

\section{References}

Anonymous. 2009. Mushroom Training and Resource Centre (MTRC) Available at: http://www.oystermushroom.ug (Accessed on $20^{\text {th }}$ January 2017).

Anonymous 2012. Nabalayo Empowers Banda Women Through Mushroom Growing. Available at: http://www.newvision.co.ug/new_vision/news/.../nabalayoempo. New vision government Newspaper published on 25th August 2012 (Accessed on 10 ${ }^{\text {th }}$ April 2017).
Anonymous. 2015. I have been growing mushrooms for 20 years. Daily Monitor Local Newspaper. Available at: http://www.monitor.co.ug/Magazines/Farming/-I-have-beengrowing-mushrooms-for-20-years-/-/689860/2820006//159pe78/-/index.html (Accessed on 10 ${ }^{\text {th }}$ April 2017).

Anonymous. 2017. Report; Uganda has the Most Entrepreneurial Women in the World: Available at: http://kenyanwallstreet.com/ report-uganda-entrepreneurial-women-world (Accessed on $18^{\text {th }}$ March 2017). 
Awasthi N, Sahu A, Sahu RP. 2015. Mushroom Production for Economic Empowerment of Rural Women in District Rama Bai Nagar, Kanpur. Advances in Social Research December 2015, 1(1): 31-33.

Ferchak JD, Croucher J. 2001. Prospects and Problems in Commercialization of Small-Scale Mushroom Production in South and Southeast Asia. Appropriate Technology International, Washington DC, USA, 321-329 pp.

Kiguli J. 2003. Mushroom Cultivation in Urban Kampala. UA Magazine, Makerere University, Uganda, 20-21pp.

Kyobutungi MC. 2014. Mushroom Growing: A Neglected but Profitable Business. Available at: http://www.chimpreports.com/mushroom-growing-a-neglectedbut-profitable-business. (Accessed on 20th December 2016).

Malakar K, Ipulet P, Byandusa P. 2016. Role of women in mushroom growing in Uganda: The case of the Mushroom Training and Resource Centre, South West Uganda. World Society for Mushroom Biology and Mushroom Products (WSMBMP) Bulletin, No: 14.

MoFPED. 2014. Uganda Poverty Status Report. Ministry of Finance, Planning and Economic Development (MoFPED). Kampala, Uganda.

Nshemereirwe F. 2004. Mushroom Cultivation in Uganda: Uganda National Council for Science and Technology (UNCST). Mushroom Growers Handbook 1. Available at: http://www.alohamedicinals.com/book1/chapter-10-3.pdf (Accessed on 18th December 2016).
OECD. 2015. Uganda SIGI Country Report. OECD Development Center. Available at: https://www.oecd.org/dev/developmentgender/ (Accessed on 10 ${ }^{\text {th }}$ April 2017).

Sathiabama K. 2010. Rural women empowerment and entrepreneurship development [Online]. Available at: http://www.microfinancegateway.org/ga (Accessed on $15^{\text {th }}$ August, 2010).

Singh J, Chahal VP, Rathee A, Singh K. 2014. Economic Empowerment of Scheduled Caste (SC) Landless Rural Women through Mushroom Cultivation: A case study. African Journal of Agricultural Research, Vol.9 (52), pp. 3811-3815, DOI: 10.5897/AJAR2013.8089 ISSN: 1991-637X.

UBOS. 2014. Uganda Agricultural Sector Gender Statistics Profile 2014. Uganda Bureau of Statistics (UBOS), Kampala, Uganda.

Valverde ME, Perez TH, Lopez OP. 2015. Edible Mushrooms: Improving Human Health and Promoting Quality Life. International Journal of Microbiology Volume: 2015. Available at: http://dx.doi.org/10.1155/2015/376387 (Accessed on 10 April 2017).

World Bank. 2014. Levelling the field: Improving Opportunities for Women Farmers in Africa. World Bank Publications No:86039, Washington DC, USA.

World Bank. 2016. The World Bank Data: Agriculture, value added the percentage of Gross Domestic Product (\% of GDP). Available

at: https://data.worldbank.org/indicator/NV.AGR.TOTL.ZS (Accessed on 10th April 2017). 